\title{
Biosolids in a Chihuahuan Desert Ecosystem
}

\section{Biosolids offer a variety of opportunities to improve semiarid rangelands.}

\author{
By David B. Wester, Ronald E. Sosebee, \\ Richard E Zartman, \\ Ernest B. Fish, and J. Carlos Villalobos
}



Figure 1. Biosolids are topically applied with a farm-type manure spreader to rangeland in west Texas.

method of land disposal. In 1998, 43\% of all biosolids in the U.S. were land-applied. Increased research and changing societal values have led to predictions that nearly $50 \%$ of all biosolids produced in 2010 may be land-applied.

Many states have regulations restricting the conditions under which biosolids can be applied. For example, biosolids usually cannot be applied during precipitation events, or when snow or ice are on the ground. Thus, semiarid areas are choice locations for year-round biosolids application because there is minimal time lost to wet or cold conditions. Southwestern rangelands have therefore received increased attention as suitable areas for land application of biosolids (Fig. 1). Wide-open spaces remote from urban areas, equable climates, and large acreages in private holdings have attracted municipal and commercial sewage disposal entities to pursue possibilities of application in desert grasslands and shrublands in Texas, New Mexico, and Arizona.

In 1992, we began a ten-year research program investigating the effects of topically-applied biosolids at a Chihuahuan desert research site. We have studied the effects of biosolids on soil properties, erosion, runoff and infiltration; soil water quality; forage production and forage quality; plant ecophysiological responses; soil nutrient cycling; and livestock performance. In this article, we highlight some of our results from these studies.

The Research Site: Our study site includes about 900 acres of grassland and shrubland in the northern Chihuahuan Desert near Sierra Blanca in
Because of the high nutrient value of biosolids, land application is the disposal method of choice. Biosolids can act both as a soil amendment, increasing soil organic matter, and as a fertilizer, increasing forage production and enhancing forage quality via recycling of valuable nutrients.

Land application is also the most economical 


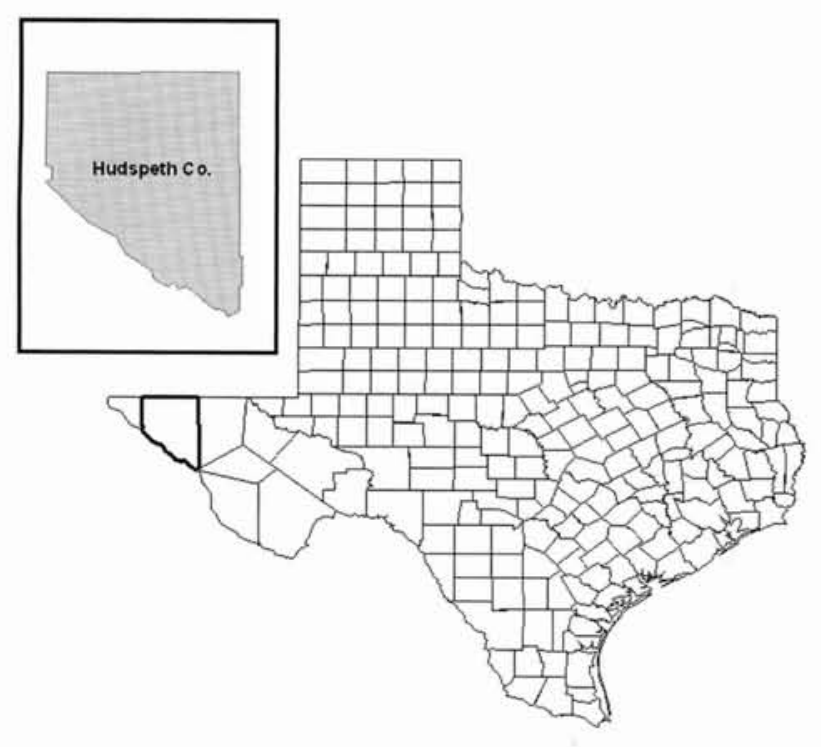

Figure 2. Map of study site in west Texas.

Hudspeth County, Texas (Fig. 2). Climate is a southwestern type, with hot summers and mild winters. Annual long-term rainfall averages 12 inches, $65 \%$ of which occurs between July and September.

Grassland areas with loamy soils are dominated by tobosagrass and alkali sacaton, with widely scattered mesquite and lotebush (Fig. 3). Fine sandy loam soils support blue grama, black grama, and assorted dropseeds with yucca and ephedra. Shrublands are dominated by creosotebush; fluffgrass and assorted dropseeds characterize the typically depauperate herbaceous component of this plant community.



Figure 3. Tobosagrass and alkali sacaton are dominant grasses in our study site, with widely scattered mesquite.
We have coordinated over a dozen research projects involving range scientists and soil scientists with a standardized methodology that includes application rates of $0,3,8,15$, and 40 dry tons/acre of biosolids on three range sites. Application rates regulated by the State of Texas range from 3 to 8 tons/acre. Our highest application rate was intended to document effects of excessive application far above amounts that would be expected in a commercial setting.

\section{Applications Increase Soil Water and Reduce Erosion}

Biosolids application has important impacts on hydrological processes both at a small scale and at a large scale. Because erosion, runoff, and infiltration of each square foot of rangeland are affected by biosolids application, we can also expect major hydrological consequences on the scale of 1,000-acre land units that are treated in commercial application projects. In order to manage large-scale applications, it is important to understand how biosolids affect the basic processes of soil water infiltration, runoff, and erosion.

We used a portable rainfall simulator to study how infiltration and runoff are affected by biosolids. The simulator applied water at a rate of 6.4 inches/hour for a 30-minute period to plots treated with $0,3,8$, 15 , or 40 dry tons/acre of biosolids on a site dominated by tobosagrass and a site characterized by creosotebush. At the loamy site, we also studied the effects of biosolids applied on top of tobosagrass plants and in bare areas between plants. Experiments required about 2 months to complete after biosolids application.

Biosolids on the soil surface reduced erosion. For example, in the bare areas between tobosagrass plants, even the lowest biosolids rate ( 3 tons/acre) reduced erosion by about $40 \%$ compared to bare areas not treated with biosolids. Increased soil water infiltration was associated with reduced erosion.

These effects are consequences of at least two factors. Topically-applied biosolids provide a surface cover that can absorb the impact of falling raindrops. This reduces the detachment of soil particles that occurs during storms. Biosolids also increase soil organic carbon, especially at the soil surface, 
which inhibits crust formation and further promotes infiltration. The net result of biosolids application is reduced soil erosion and runoff and increased soil water infiltration.

\section{Soil Water Quality Not Reduced}

Soil water quality issues relate to quality of water that infiltrates into a treated soil, and also to the water that runs off of a treated soil. Our research has investigated both of these concerns.

The quality of water that had passed through soils treated with biosolids was studied with microlysimeters constructed of 10 -inch polyvinyl choride well casing. Tubes 2 to 3 feet in length were inserted into a loam soil dominated by tobosagrass and a fine sandy loam soil dominated by black grama, extracted with a soil column intact, and transported to an on-site indoor laboratory. In one experiment, we applied biosolids to the soil surface. Water was hand-sprinkled to simulate rainfall until sufficient leachate was collected from the bottom of the lysimeter for chemical analysis. The leachate was analyzed for chloride, nitrate-nitrogen, $\mathrm{pH}$, orthophosphates, sulfates, calcium hardness, and total hardness; also, we analyzed for 20 elements including aluminum, beryllium, cadmium, copper, iron, lead, and molybdenum.

In general, when biosolids affected concentrations of the elements we tested, these effects were observed at the highest application rate of 40 tons/acre. In fact, our measurements indicated that leachate from soils treated at rates up to 15 tons/acre was generally within USEPA drinking water standards. Our results suggest that soil water quality associated with topical application of biosolids should not be a concern.

However, when we repeated this experiment but mixed biosolids into the top four inches of the soil in the lysimeters, we found markedly different results. For example, incorporation in the surface soil increased the release of mobile constituents such as nitrate-nitrogen, sulfate, and chloride. Nitrate-nitrogen was never below drinking water standards even in 0 tons/acre lysimeters.

This indicates that soil water quality may be affected by soil disturbance, even in the absence of biosolids, as well as by biosolids. Our results suggest
The USEPA has established maximum contaminant levels for health-related trace contaminants in drinking water. A trace contaminant is defined as an element or compound with a standard tolerance level allowed which is generally less than $1 \mathrm{ppm}$. Secondary maximum contaminant levels that affect aesthetic quality of drinking water have also been established; secondary maximum contaminant levels are not related to health issues.

that water quality of leachate is well within the range of drinking water standards when biosolids are topically applied at commercially-regulated rates.

\section{Runoff Water Quality Is Acceptable}

We also studied the quality of runoff water from biosolids-treated soils. All of the trace elements and compounds for which a maximum contaminant level has been established were below this level in our runoff water. Likewise, those elements and compounds for which a secondary maximum contaminant level has been established were well below this level except for manganese. Runoff water thus generally meets USEPA standards for drinking water at all application rates except 40 tons/acre of biosolids.

\section{Little Ammonia Nitrogen Is Lost}

State and federal regulatory agency guidelines for biosolids application are based on the balance between nitrogen needs of a plant and "plant available nitrogen" supplied by biosolids. This approach is used because nitrogen in biosolids can be lost via ammonia volatilization; thus, plant available nitrogen is more important than total nitrogen in establishing application rates that are beneficial for plant growth.

We studied ammonia volatilization from biosolids as it was influenced by "hot" (68 to $97^{\circ} \mathrm{F}$ ), "intermediate" (43 to $73^{\circ} \mathrm{F}$ ), or "cool" ( 25 to $57^{\circ} \mathrm{F}$ ) temperatures. Less than $10 \%$ of the applied ammonianitrogen was lost via volatilization in the first three days following 3 tons/acre application under cool conditions; under hot conditions, about $16 \%$ of the ammonia-nitrogen was volatilized within three days. 
Air temperature is especially important in the volatilization process during the first few days following biosolids application. Slow drying conditions allowed for more volatilization to occur over a longer time period than when drying was rapid.

Air temperature during and after application also can affect degradation of biosolids. We studied this issue by measuring $\mathrm{CO}_{2}$ losses over a 29-day period from biosolids applied to a clay loam soil in a sealed, forced-air chamber. The conditions in the chamber [three temperatures $\left(41,73\right.$ or $\left.100^{\circ} \mathrm{F}\right)$ and two initial gravimetric soil water contents (5 or $15 \%)]$ were similar to conditions at the field test site at Sierra Blanca, Texas.

Immediately after biosolids application, we detected an initial loss of $\mathrm{CO}_{2}$ that was not caused by microbial degradation. For the next 52 hours of the experiment following this initial $\mathrm{CO}_{2}$ loss, carbon loss increased significantly as temperature increased. After this time, however, carbon loss was not related to temperature. Since temperature does not affect carbon loss beyond 2 days after application, and we measured carbon loss even at temperatures as cool as $41^{\circ} \mathrm{F}$, we conclude that biosolids may be applied throughout the year (local weather permitting).

\section{Increased Forage Production}

In addition to adding micro- and macro-nutrients, biosolids on the soil surface provides a physical mulching effect that moderates soil surface temperatures and reduces soil water evaporation. These benefits are expected to vary depending on rate, season, and frequency of biosolids application. Several of our studies investigated the combined effects of rate ( 0 to 40 tons/acre), season (dormant or growing), and frequency (1 year only, or 2,3 , or 4 consecutive years) of biosolids application on tobosagrass and alkali sacaton forage production. We also studied the effects of supplemental irrigation.

The impact of season of application on grass production was important only during the first growing season following application. Standing crops of tobosagrass and alkali sacaton were enhanced more when biosolids were applied during the previous dormant season (early March) than during the growing season (early July). Standing crop of these



Figure 4. Tobosagrass forage production at the end of 1996 in nonirrigated plots that were treated with biosolids for one year only (in 1993), or for two years (1993, 1994), three years (1993-1995) or four years (1993-1996).

species during the second and subsequent growing seasons was not affected by season of application.

In general, although standing crop increased as biosolids application rate increased, it increased at a decreasing rate (Fig. 4). Standing crop usually decreased at the 40 tons/acre rate, especially after multiple applications, compared to lower application rates. However, in almost every case we investigated, standing crop in treated plots equaled or exceeded standing crop in untreated plots. We conclude that biosolids generally have a neutral or positive effect on aboveground production of these species. And from our irrigation studies, we learned that the beneficial effects of biosolids on forage production did not depend on water availability.

Measurements of standing crop are productionoriented indices of plant response to biosolids. We also investigated how biosolids applications affect leaf area, photosynthesis, and water use efficiency of tobosagrass and blue grama.

In general, leaf area was increased by biosolids when soil water was adequate. Tobosagrass photosynthesis on the first day following irrigation was also increased by biosolids application; although photosynthesis decreased thereafter, it was still higher in irrigated and biosolids-treated plants than in untreated plants. Blue grama had higher photosynthetic rates when treated with biosolids. Biosolids application also increased water use efficiency of our plants. Greater leaf area and higher photosynthetic rates are involved in overall plant pro- 
duction responses to biosolids, especially when soil water is not limited. Under limiting soil water conditions, biosolids appear to exert a beneficial effect on Jlant growth by improving water use efficiency.

\section{Forage Quality Is Improved}

Although increasing forage production with biosolids is an important benefit to a producer, it is equally important that the nutrient quality of the forage is enhanced by biosolids. After a one-timeonly autumn application of biosolids, we detected increases in plant total kjeldahl nitrogen, magnesium, manganese, and sodium in leaf and stem material. For elements that showed increases as a result of biosolids application, none are increased to levels considered excessive or toxic. Additionally, increases in plant nitrogen from a single biosolids application carried over for at least four years after application (Fig. 5).

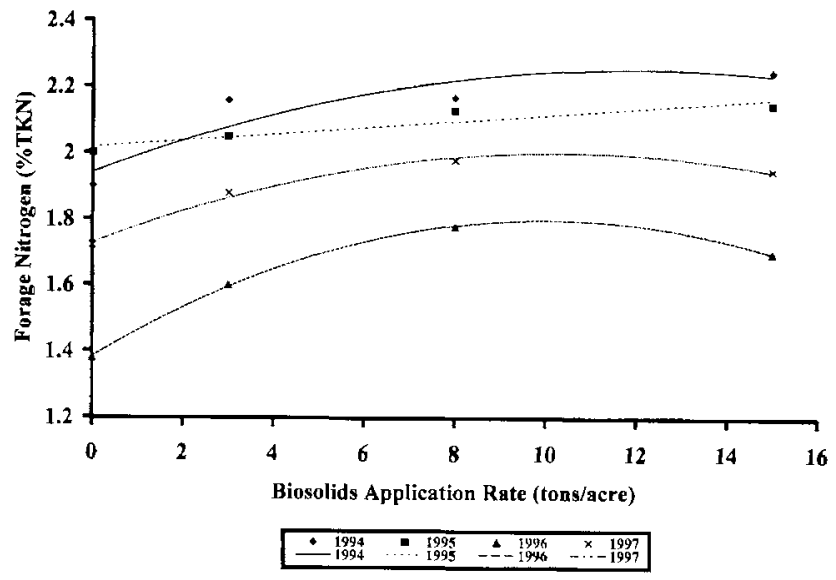

Figure 5. Tobosagrass forage nitrogen in plants that were treated in 1994, and measured in 1994, 1995, 1996, or 1997.

\section{Plant Establishment Can Be Enhanced}

Semiarid rangelands are often unfavorable environments for plant establishment. Low soil moisture and extreme soil temperatures limit opportunities for seed germination and seedling establishment, making rehabilitation efforts both expensive and unpredictable. We would expect the soil coverage created by topically-applied biosolids to modify microenvironmental conditions and thus potentially affect plant establishment.
In greenhouse and field studies, biosolids often reduced maximum soil surface temperatures and increased minimum soil temperatures, thus moderating extreme temperature fluctuations. The mulching effect of biosolids usually reduced soil water evaporative losses.

These microenvironmental changes were expected to improve seedling emergence. Results suggested, however, that plant response to these conditions is complicated by the degree of severity of the prevailing environment. Under excessively harsh conditions (e.g., no rainfall and extremely high temperatures), the beneficial effects of biosolids were simply inadequate to overcome the forbidding environment. In contrast, under more favorable conditions (e.g., following plentiful rainfall), seedling emergence was similar in sites treated with biosolids and in nontreated sites-the benefits provided by biosolids were not needed by emerging seedlings. Under intermediate conditions, however, topicallyapplied biosolids improved seedling emergence and prolonged the conditions needed for seedling survival. Thus, we anticipate long-term benefits of biosolids application to increase plant density, but these effects will depend on moisture and temperature conditions during the time of seed germination and seedling establishment.

\section{Livestock Response}

With increased forage production and improved forage quality, we would expect the benefits of biosolids application to be seen in animal performance as well. Results suggest that stocker cattle grazing biosolids-treated rangeland dominated by blue grama, sand dropseed, black grama, and burrograss gained up to half a pound more per head per day than cattle grazing nontreated rangeland, under favorable growing conditions the year after application. Our grazing behavior studies showed that steers selected biosolids-treated vegetation about $56 \%$ of the time when they had free choice between treated and nontreated rangeland (Fig. 6). Cattle grazing on biosolids-treated rangeland had similar in aluminum, cadmium, copper, magnesium, manganese, lead, and zinc contents compared to cattle grazing similar but non-treated range. These results suggest that with proper management, biosolids ap- 


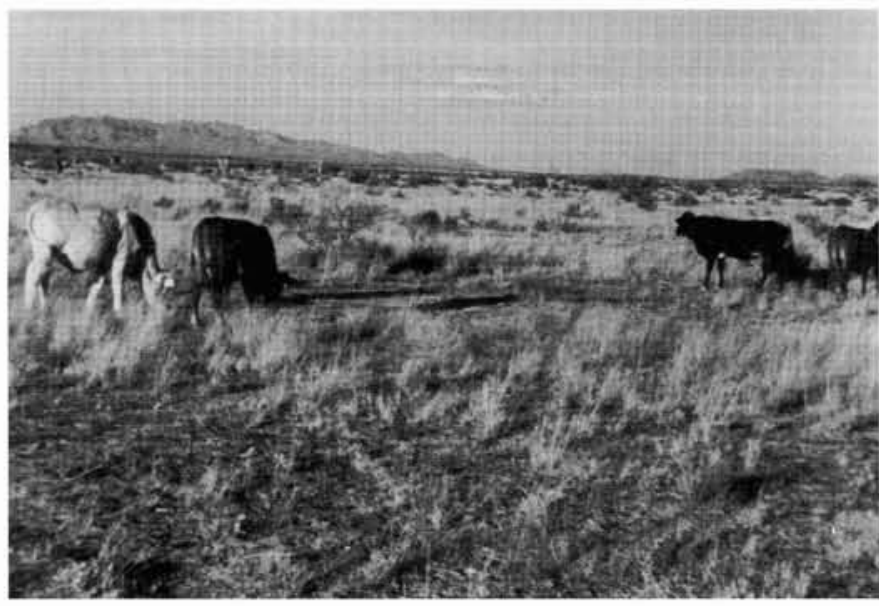

Figure 6. Grazing studies showed that cattle can have higher gains on biosolids-treated rangelands during favorable periods.

plication to rangeland can improve animal performance under favorable conditions.

\section{Conclusions}

Municipalities nation-wide are producing increasing amounts of biosolids. Although at the site of production they may be considered a waste, biosolids have high organic matter and nutrient content and are therefore a valuable natural resource which, if not recycled, will indeed be wasted. We have studied the effects of biosolids on a Chihuahuan desert ecosystem for 10 years. Based on our results, "beneficial use" application, a regulatory term of the EPA, may also be accurate in an ecological sense.

When biosolids that are free from excessive trace elements and pathogens are topically applied to arid and semiarid rangelands in accordance with responsible regulation and on-site management, our results show that a host of consequences follows, including:

- reduced soil erosion and soil water runoff,

- increased soil water infiltration,

- acceptable soil water quality,

- enhanced plant water use efficiency,

- increased forage production,

- improved forage quality, and

- enhanced animal performance.

The application of biosolids to rangelands must be integrated with overall management goals and objectives, and range managers and land applicators will have operation-specific needs and constraints.
Nevertheless, from most perspectives, the benefits that follow from responsible application of biosolids to southwestern rangelands will lead to overall rangeland improvement.

About the authors: D.B. Wester, R.E. Sosebee, E.B. Fish and J.C. Villalobos are faculty members in the Department of Range, Wildlife, and Fisheries Management, Texas Tech University; R.E Zartman is a faculty member in the Department of Plant and Soil Science, Texas Tech University. Research summarized in this paper was supported in part by MERCO, A Joint Venture, the State of Texas, CH Foundation, and San Antonio Livestock Exposition.

The authors would like to thank B.L. Allen, M. Avila, M. Benton, C. Brenton, S. Casby-Horton, P. Cooley, R. Gatewood, J. Hahm, D. Harmel, W. Jaynes, P. Jurado, R. Mata-Gonzales, C. Moffet, M. Rostagno, C. Shanks, R. Strait, S. Yan and C. Wan for their contributions to this research. This is publication no. T-9-947, College of Agricultural Sciences and Natural Resources.

*Address correspondence to: david.wester@ttu.edu or Ron.Sosebee@ttu.edu

\section{References}

Benton, M.W. and D.B. Wester. 1998. Effects of topically applied biosolids on tobosagrass and alkali sacaton growth in a Chihuahuan desert grassland. J. Environ. Quality. 27:199-208.

Harmel, R.D., R.E. Zartman, C. Mouron, D.B. Wester, and R.E. Sosebee. 1997. Modeling ammonia volatilization from biosolids applied to semiarid rangelands. Soil Sci. Soc. Am. J. 61:1794-1798.

Jurado, P. and D.B. Wester. 2001. Effects of biosolids on tobosagrass growth in the Chihuahuan desert. J. Range Management 54:89-95.

Rostagno, C.M. and R.E. Sosebee. 2001. Biosolids application in the Chihuahuan Desert: Effects on runoff water quality. J. Environmental Quality 30:160-170.

Strait, R.K., R.E. Zartman, R.E. Sosebee, and D.B. Wester. 1999. Evaluating temperature constraints for municipal biosolids application to a desert grassland soil. Texas J. Agriculture and Natural Resources. 12:80-87.

USEPA, 1999. Biosolids generation, use and disposal in the United States. EPA530-R-99-009. USEPA, Washington, DC. 